\title{
Rare Soft Tissue Localized Distal Femur Parachordoma: Case Presentation
}

\section{Nadir Görülen Femur Distal Yumuşak Doku Yerleşimli Parakordoma: Olgu Sunumu}

\author{
Güray Toğral ${ }^{1}$, Murat Arıkan ${ }^{1}$, Fisun Ardıç Yükrük ${ }^{2}$, Fatih Eksioğlu ${ }^{1}$, Şafak Güngörr ${ }^{1}$ \\ ${ }^{1}$ Dr. A. Y. Ankara Onkoloji Eğitim Ve Araştırma Hastanesi, Ortopedi Ve Travmatoloji Kliniği \\ ${ }^{2}$ Dr. A.Y. Ankara Onkoloji Eğitim Ve Araştırma Hastanesi, Patoloji Kliniği
}

DOI: $\underline{10.5505 / \text { aot.2011.36854 }}$

\section{ÖZET}

Parakordoma myoepitelyoma olarak da isimlendirilen aksiyel dışı yerleşimli histolojik olarak kordomaya benzeyen yumuşak dokuların son derece nadir görülen bir tümörüdür. Bu nadir tümör ekstra-aksiyel kordoma, parakordoma ya da kordoma periferikum olarak da adlandırılmaktadır. Lezyonlar daha sıklıkla erkeklerde görülür. Alt ekstremite en sık görülen lokalizasyon bölgesidir. Tedavisi öncelikle cerrahidir. İyi huylu bir tümör olmasına rağmen lokal agresif bir davranış gösterebilmektedir. Geç rekürrens gösterebilmekle birlikte nadirde olsa akciğer metastazı yapma potensiyelleri vardır. Bu olguda uyluk distalinden kaynaklanan ve çok nadir görülen bir parakordoma olgusu incelenmiştir.

Anahtar Kelimeler: Parakordoma; femur distali; geniş rezeksiyon; histopatolojik bulgular.

\section{ABSTRACT}

Parachordoma, also named as myoepithelioma, is a rare,non axially located soft tissue tumor histologically resembling chordoma. This rare entity is also named as extra-axial chordoma, parachordoma and chordoma periphericum. Lesions are generally seen in male patients and located at the lower extremities. The primary treatment modality is surgery. Even this tumor is benign, it may show local aggressive potential. Late local recurrences can be expected and pulmoner metastases are seldom. In this case presentation, a rare parachordoma case located at the distal femur is evaluated.

Keywords: Parachordoma; distal femur; wide resection, histopathological findings

\section{Giriş}

Parakordoma, myoepitelyoma olarak da isimlendirilen aksiyel dışı yerleşimli histolojik olarak kordomaya benzeyen yumuşak dokuların son derece nadir görülen bir tümörüdür. Kökeni tam olarak açıklanamamaktadır. İlk olarak 1951 yılında 'chordoma periphericum' adı altında Laskowski tarafından tanımlanmıştır.

1977 y1lında ise Dabska 10 olguluk bir seride bu olguları parakordoma ismi ile bildirmiştir (1). İngiliz literatüründe 50 den fazla bildirilen olgu vardır (2). Parakordoma yavaş büyüyen, nadiren geç metastaz yapan, metastaz yapma potansiyeli düşük bir yumuşak doku tümörüdür. Histolojik olarak kordomaya benzeyen ve çok çeşit varyasyonlar gösterebilen bir tümördür.

\section{Olgu Sunumu}

Elliyedi yaşında kadın hasta yaklaşık 3 yıldır devam eden sol dizde ağrı ve şişlik şikayeti ile polikliniğimize başvurdu. Son 3 ayda şikayetleri artma gösteren hastanın herhangi bir travma hikayesi yoktu. Fizik muayenede sol uyluk alt uç iç kesimde yaklaşık $5 \times 4$ cm'lik sert hareketsiz kitlesi olan hastanın kasık lenf bezi muayenesi normaldi. Başlangıç olarak direk grafi ve manyetik rezonans görüntüleme (MRG) ile değerlendirme yapıldı. Direk grafide uyluk alt ucunda iç kemik yapıda minimal hasar oluşturan, kitle imajı veren görünüm mevcuttu. MRG'da sol uyluk alt uç kesimde dışarı doğru taşan yumuşak doku bileşeninin eşlik ettiği ve komşu uyluk iç kemikte yıkıma neden olan yaklaşı $11 \times 9 \mathrm{~cm}$ boyutlarında T1 ağırlıklı sekanslarda hipointens T2 ağırlıklı sekanslarda hiperintens 
sinyal özelliğinde kötü huylu görünüme sahip kitle lezyonu mevcuttu (Resim 1 A,B,C).

MRG'de spesifik olmayan yumuşak doku kitlesi görünümü nedeniyle ayırıcı tanıda malign fibroz histiyositom, fibrosarkom, metastatik hastalıklar öncelikle düşünüldü. Hastaya açık biyopsi planland. Evreleme tetkiklerinden toraks bilgisayarlı tomografide (BT) metastaz yokken; batın BT'de karaciğerde bir adet kitle imajı veren şüpheli lezyon mevcuttu. Yapilan incelemelerde bu lezyon metastaz olarak yorumlanmazken takibe alındi. Hastaya yapılan açık biyopsi sonucu parakordoma ile uyumlu bulgular gelmesi üzerine hastaya geniş tümör rezeksiyonu ve modüler tümör diz protezi ile rekonstrüksiyon ameliyatı yapıldı. (Resim 1D).

Mikroskobik incelemede kondromiksoid stromada fibröz septalarla lobül yapılarına ayrılan, kordon, grup ve kümeler oluşturan tümöral doku izlenmekteydi (Resim 2A). Tümoral doku, santral yerleşimli yuvarlak oval eozinofilik veya intrasitoplazmik vakuol içeren sitoplazmalı yuvarlak veya piknotik nükleuslu belirgin atipi göstermeyen hücrelerden oluşmaktayd 1 (Resim 2B). Bu histolojik özelliklerle karsinom metastazı, sinoviyal sarkom, ekstraskeletal miksoid kondrosarkom, parakordoma (ektomezenkimal kondromiksoid tümör), kordoma periferikum, yumuşak dokuların myoepitelyoması, mikst tümör, subkutanöz miksopapiller epandimom yumuşak dokuların ossifiye fibromiksoid tümörü (OFMT-SP), epiteloid sarkom myoepitelyal karsinomu da içine alan, hasta yaşına ve anatomik lokalizasyonuna bağlı olarak geniş bir ayırıcı tanı listesi oluşturuldu. Tümör hücreleri EMA (Epitelyal Membran Antijen), CK8/18 (Cytokeratin), panCK (Cytokeratin), Vimentin ile diffüz S100 ile fokal soluk olarak boyandi. Olgu parakordoma/ myoepitelyoma/ ekstraaksiyal kordoma olarak raporland1.

Ameliyat sonrası nörolojik komplikasyon olmayan hastaya 2. gün pasif diz hareketlerine başlandı. Hasta 5. gün ayağa kaldırıldı. SPH (sürekli pasif hareket) cihazı ile diz fleksiyonunda 15 . günde 90 dereceye ulaşıldı.

\section{Tartışma}

Parakordomalar, geç rekürrens ve metastaz yapma potansiyeline sahip tümörlerdir. Önceleri parakordomaların; aksiyel dışı yerleşimli kordomalar olduğuna inanılırken şimdilerde bu tümörlerin ESWR1 (Ewing's Sarcoma Region 1) gen translokasyonu gösterebilmesi nedeniyle bağımsız farklı bir olgu olduklarına inanılmaktadır (3).

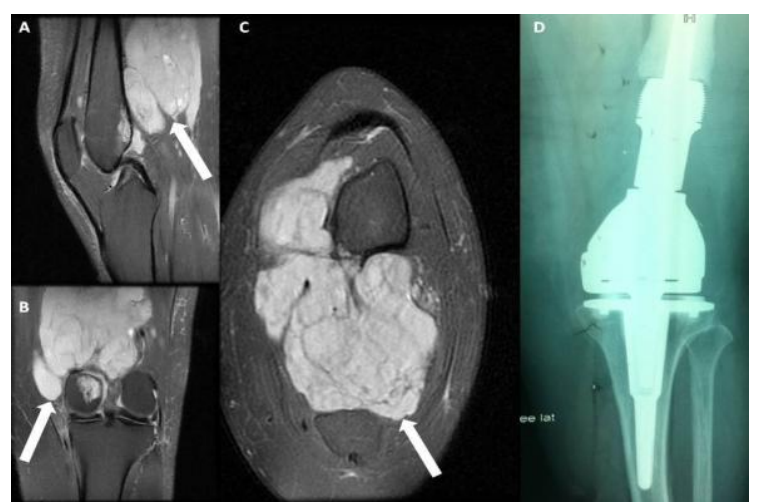

Şekil 1 (A-D) Femur distalinde posteriyor ağırlıklı yerleşim gösteren ve medial kondile invazyon yapan T2 ağırlıklı sekanslarda hiperintens sinyal özelliğinde lobule düzensiz kontürlü parakordoma olgusunun sirasiyla sagital (A), koronal (B), aksiyel (C) MRI görüntüsü (D) Hastanın post operatif $\mathrm{x}$-ray A-P tümör rezeksiyon protezi görüntüsü

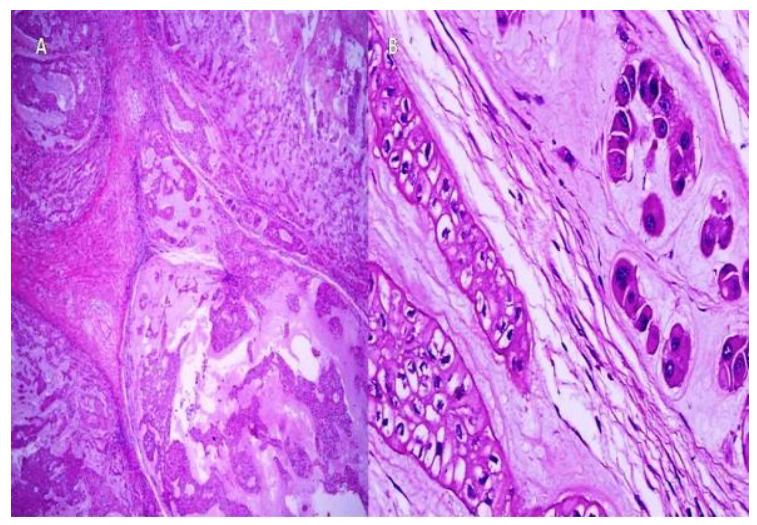

Şekil 2 (A). Küçük büyütmede lobüler büyüme paterni gösteren tümör HE,X40 (B). Santral yerleşimli yuvarlak /oval nukleuslu, eozinofilik/ vakuole sitoplazmalı belirgin atipi göstermeyen hücreler, HEX400

$\mathrm{Bu}$ gurup anatomik lokalizasyonuna bağl1 olarak değişen terminolojiye sahip bir grup tümörü temsil eder. WHO (World Health Organization) 2013 de pleomorfik adenom (tükrük bezi), benign mikst deri tümörü, yumuşak doku myoepitelyoması ve parakordoma ortak olarak isimlendirilmiştir. $\mathrm{Bu}$ spektrumdaki olguların \%40'1 malign olmakta olup bunlar myoepitelyal karsinom olarak isimlendirilmektedir. İmmünhistokimyasal (İHK) olarak myoepitelyal diferansiyasyon EMA, CK ve S100 pozitifliği ile saptanır. 
Siklıkla ekstremitelerin komşu bitişik tendon sinovyum ya da kemik yapıları, gögüs duvarı, kalça, el ve gastrik serozadan köken alır. Pelviste iki kez daha sıklıkla bildirilmiştir (4). Parakordoma sıklıkla yetişkinlerde görülmekle birlikte 101 olguluk bir seride bildirilen yaş aralığ 3-83 olup ortalama yaş 39 dur (5).

Terminolojisi henüz oturmamış bir tümör grubudur. Parakordoma ifadesi histolojik olarak santral kordomaya benzediği için kullanılan bir terim olmuştur. Bu lezyonlar için birkaç yıl önce myoepitelyoma terimi önerilmiştir. Son genetik çalışmalar bu tartışmaları yeniden alevlendirmiş ve ESWR1 geni tranlokasyonu gösteren olgular tanımlanmıştır. 2013 WHO, mikst tümör, myoepitelyoma/parachordoma terimlerinin bir fikir birliğine varılana dek kullanılmasının uygun olduğunu kabul etmiş ve bu konuda kesin çözüme genetik çalışmalarla geniş seriler incelenebilirse ulaşmanın mümkün olacağ1 vurgulanmaktadır.

$\mathrm{Bu}$ lezyonlarda cinsiyet ayırımı sıklığı konusunda tam olarak bir fikir birliği olmasa da daha sikl1kla erkeklerde görülür. Alt ekstremite en sik görülen lokalizasyon bölgesidir (6-8). Bizim olgumuzda hasta 57 yaşında, bayan ve tümör alt ekstremite yerleşimli idi.

Parakordoma olgularının geleneksel kondrosarkom ve ekstraskeletal miksoid kondrosarkom olgularından ayırımı önemlidir. Çünkü bu tümörler sıklıkla lokal tekrarlama ve uzak metastaz yapma potansiyeline sahiptirler (9).

Parakordomalı hastalar genellikle yavaş büyüyen ağrısız kitle şikayeti ile kliniğe başvururlar. Tümör genellikle iyi sınırlı olup ince bir fibröz yalancı kapsülle çevrilidir.

\section{Kaynaklar}

1. Dabska M. Parachordoma: a new clinicopathologic entity. Cancer 1977;40:1586-92

2. Kinoshita G, Yasoshima H. Case report: fatal parachordoma.J Orthop Sci 2007;12:101-6

3. Van Akkooi ACJ, Van Geel AN, Bessems JHJM, Bakker MA. Extra-axial parachordoma.

J Bone Joint Surg 2006;88:1232-4

4. Huang CC, Cheng SM. Clinical and radiological presentations of pelvic parachordoma. Rare Tumors 2012;4:e5

5. Silverberg's Principles and Practice of Surgical Pathology and Cytopathology. 4th ed, Philadelphia, Churchill Livingstone, 2006,395-6
Makroskobik olarak kitle genellikle lobüle ve nodüler bir görünüme sahiptir. Kitle boyutu 3$7 \mathrm{~mm}$ den başlayarak $12 \mathrm{~cm}$ kadar ulaşabilmektedir. Komplet cerrahi rezeksiyon genellikle tek başına tedavi edicidir. Literatürde cerrahi marjin ve rekkürrens arasında ilişki konusunda çelişkili ifadeler vardır. Cerrahi tedavi tek başına pek çok vakada kür sağlamaktadır. Yetersiz cerrahi uygulanan vakalarda tümörün tekrarlama ihtimali yüksektir. Parakordama iyi huylu bir tümör olmakla birlikte metastaz ve tekrarlama ihtimali vardır. Metastatik parakordoma olgularında çok farklı kemoterapi uygulamaları olabilmektedir (10). Tekrarlama ve uzak metastaz nadir olmakla birlikte, 45 vakalık bir seride 3 ay ile 12 yıl arasında değişen sürelerde bildirilen nüks olgular vardır (11). Parakordoma da metastaz ilk kez Miettinen ve ark. tarafından 67 yaşında akciğer metastazı olan bir olguda bildirmişlerdir (12). Hastamız postoperatif 2. y1lında olup nüks ve metastazı yoktur.

Parakordoma olgularında primer bölgenin takibi potansiyel rekürrens olma olasılığı taşıması açısından anlamlıdır. Uzun süreli takiplerde görüntüleme yöntemi olarak akciğer BT ve kemik sintigrafisi faydalıdır (13).

$\mathrm{Bu}$ olguda 57 yaşında bacak alt kesimde kemikte yıkım yapan parakordoma tanılı hasta nadir görülmesi ve kitle boyutunun büyük olması nedeniyle bildirilmiştir. Yayınlar göstermektedir ki parakordoma nadirde olsa metastaz yapma ve geç nüks etme ihtimali bulunması nedeniyle doğru tanı konulması, tedavi edilmesi ve devamında yakın takip edilmesi gereken bir yumuşak doku sarkomudur.

\section{Çıkar Çatışması: Yok}

6. Clabeaux J, Hoinowski L, Valente A, Damron TA. Case report: parachordoma of soft tissues of the arm. Clin Orthop Relat Res 2008:466:1251-6

7. Fisher C. Parachordoma exists — but what is it? Adv Anat Pathol. 2000;7:141-8

8. Folbe AL, Agoff SN, Willis J, Weis SW, Parachordoma is immunohistochemically and cytogenetically distinct from axial chordoma and extraskeletal myxoid chondrosarcoma. Am J Surg Pathol. 1999;23:1059-67

9. Zhang J, Wang H, Cheng X, Wang M, Zhu Y. A case of parachordoma on the chest wall and literature review. J Cancer Res Ther 2013;9:114-7 
10. Guedes A, Barreto BG, Barreto LG et al. Metatstatic parachordoma. J Cutan Pathol 2009;36:270-3

11. Fisher C, Miettinen M. Parachordoma: A clinicopathologic and immunohistochemical study of four cases of an unusual soft tissue neoplasm. Ann Diagn Pathol 1997;1:3-10

12. Miettinen Gannon FH, Lackman R. Chordomalike soft tissue sarcoma in the leg: a light and electron microscopic and immunohistochemical study. Ultrastruct Pathol 1992;16:577-86
13. Estrems Díaz V, Bertó Martí FX, Zarzuela Sánchez V, Cabanes Ferrer MI, Bru Pomer A. Parachordoma of soft tissues of the arm: a very rare tumour. Case Rep Orthop 2013;2013:252376 